\title{
Khuff Formation in Kuwait: An Overview
}

\author{
Riyasat Husain (Kuwait Oil Company <rhussain@kockw.com>), Dabeer Ahmad Khan \\ (Kuwait Oil Company < dkhan@kockw.com>), Abdulaziz Sajer (Kuwait Oil Company) and \\ Nada Al-Ammar (Kuwait Oil Company)
}

The Khuff Formation represents an intra-Late Permian, Tatarian transgression over a varied topography in Kuwait. The formation occurs at greater depth in comparison to adjoining regions and is fully penetrated only in the wells located over the Kuwait Arch. The formation comprises mainly dolomudstone, foraminiferal and algal dolowackestone, peloidal and algal dolopackstone, peloidal and oolitic dolograinstone, anhydrite and minor limestone deposited in evaporitic low energy inner to middle ramp setting. Dominantly supratidal to subtidal, restricted setting and hypersaline conditions were prevailing during the deposition. Dolomitization has caused rare development of intercrystalline porosity, however mostly over dolomitization coupled with anhydrite cementation has deteriorated the porosity. Biostratigraphic and strontium-isotope analyses are indicative of a Wordian to Capitanian (Middle Permian) for the Lower Khuff while the Upper Khuff ranges in age from Wuchiapingian (Late Permian) at its base to Induan (Early Triassic) at its top.

\section{Sequence Stratigraphy}

The formation represents a second-order transgressive-regressive sequence composed of six third-order depositional sequences (Khuff sequences KS1 through KS6; Figure 1). Composite sequences KS6, KS5 and transgressive systems tract of KS4 are characterized by relatively thick anhydrite intercalations and represent the lower Khuff transgression, while the highstand systems tract of sequence KS4 and composite sequences KS3, KS2 and KS1 are more carbonate-dominated with thinner and less common anhydrite intercalations and represent a regressive phase marked by progradation back towards the east. The top of the Median Anhydrite, a persistent anhydritic bed identified regionally, which lies immediately below the maximum flooding surface of the Khuff, represents the point of maximum transgression for the second-order sequence.

\section{Controls on Thickness and Diagenesis}

The Khuff isochore map from seismic interpretation and well log correlation shows less thickness of the formation over the Kuwait Arch and greater thicknesses in western Kuwait. The thickness variations suggest that the Kuwait Arch subsided at a lower rate than western Kuwait. Also extensive dolomitization characterize the formation over the Kuwait Arch. In contrast, a greater abundance of grainy facies and a much more limestone-rich mineralogy in western Kuwait combine to yield the better porosities in areas away from the Kuwait Arch. These observations lead to conclude the existence of the Kuwait Arch during the deposition of Khuff.

\section{Qusaiba-Khuff Petroleum System}

A speculative petroleum system, namely the Qusaiba-Khuff (?) Petroleum System, is envisaged based on available exploration data. The source rock is believed to be Silurian Qusaiba Formation, which is speculated to be preserved off the flanks of the Kuwait Arch. Peak oil generation probably occurred in Late Triassic or Early Jurassic time. The porous grainy intervals in the Upper Khuff in western Kuwait and fractured dolomites within the Lower Khuff in the areas over the Kuwait Arch are envisaged to be the reservoirs. The shallow-marine to sabkha shales of the Sudair Formation are expected to act as the top seal 
for the petroleum system. Additionally the Median Anhydrite and intra-formational anhydrites and tight dolomites can provide local seals. The basin was flooded with hydrocarbon that is evidenced by direct as well as indirect events. Gas indications have been observed in many wells drilled over and in the flank of the Kuwait Arch. The presence of bituminous material in varying quantity in the entire Khuff section, more predominantly in the Upper Khuff section, is direct evidence whereas presence of $\mathrm{H}_{2} \mathrm{~S}$ and late stage calcite crystallization are indirect evidence of presence of hydrocarbon.

The major challenges for exploration of Khuff in Kuwait are timing of hydrocarbon generation and expulsion relative to trap formation in western Kuwait and predictability of reservoir quality due to diagenetic heterogeneity variation in eastern Kuwait. Detailed studies on structural evolution of western Kuwait and depositional and diagenetic modeling for reservoir quality predictability are keys to exploration success.

\section{Acknowledgements}

The authors express their thanks to the Ministry Of Oil, the State of Kuwait and Management of Kuwait Oil Company (K.S.C.) for permission to publish this work. The keen interest shown by Mr. Ahmad Jaber Al-Eidan, Manager Exploration, and Mr. Abdulaziz Mohammed Al-Fares, Team Leader for Exploration Studies, is gratefully acknowledged.

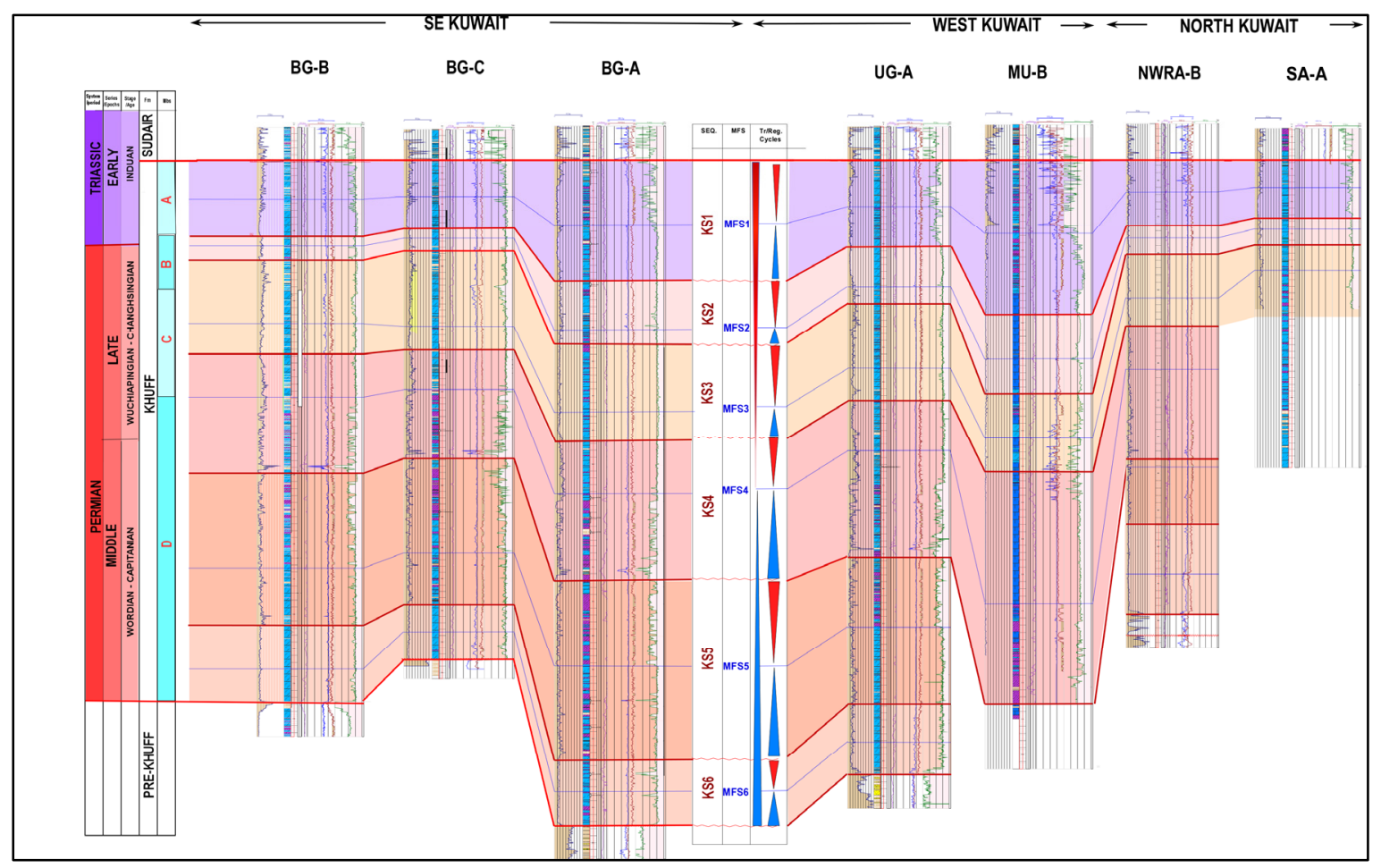

Figure 1: Sequence-Stratigraphic Framework of Khuff Formation. 